\title{
Environmental Changes and Social Vulnerability in an Ageing Society Portugal in the Transition from the 20th to the 21st Centuries
}

\author{
Maria João Guardado Moreira
}

\section{Introduction}

$\mathrm{O}$ ne of the main structural changes faced by human societies is demographic ageing, which has a strong impact on health systems and quality of life. Dependence and disability do not constitute an inevitable consequence of human ageing, but situations of fragility and vulnerability increase with age. In this scenario, the need for assistance emerges as one of the most urgent problems, on which the future of sanitarian and social policies in all developed countries will depend.

The majority of variations observed in the individual ageing process is due to social and environmental factors. The functional and cognitive deterioration that comes with age is a consequence of getting old, but it depends on individual lifestyles and environmental characteristics. Interferences in one of them will cause major global benefits, and guarantee higher independence levels, better quality of life and improved health status. Social and environmental factors can be used as predictors for health conditions, functional and cognitive autonomy, wellbeing and satisfaction in ageing. Reduced income, low educational level, and situations of loneliness may also be identified as predictive factors of higher and premature health deterioration. Better knowledge of environmental and social change effects on people will allow for better understanding of the process of vulnerability and of multiple dependency situations. The adaptation of social structures must be a priority in all ageing societies.

Portugal will also have to find answers to these challenges, despite being in a context of disadvantage due to a structurally weak health system. Besides, the ageing process is due to dissimilar situations that reflect socio-economic and environmental disparities, on which the case study for this paper will be based. 
The main objective of this study is to understand the process of vulnerability and multiple dependency situations caused by changes in the Portuguese demographic structure, manly regarding old people, as concerns the following aspects: a) levels of well-being in ageing regions determined by a statistical indicator that sums up and stratifies populations under so-called "global indicators of demographic, economic and social wellbeing", for every region of Portugal (continent) between 1993 and 2004 (this indicator includes different variables such as demographic indicators, the offer of health resources /services and economic and social characteristics; b) specific health care and long-term care provision (health statistics, National Network for Integrated Continuous Care).

Discussion of results: a combination of analyses to determine levels of regional differences in what concern vulnerability and dependency of elderly people. To overcome differences and respond to change in the social structures new health policies have to be introduced, which includes the commitment of political sectors, economic leaders and common citizens.

\section{The Demographic Dynamics}

The evolution of the Portuguese population from the second half of the $20^{\text {th }}$ century is characterised by a new demographic model of moderate growth. The constant decrease of fertility, which in 2007 amounted to 1.33 children per woman ${ }^{1}$, and the migratory fluxes explain most of the growth dynamics (from 2002 to 2007, $9 \%$ in terms of natural growth and $91 \%$ from migration). This led to some unprecedented social and demographic changes.

In the European context, the process of the demographic transition in Portugal was slow and late, but in only three decades (1975-2000) new and radical trends emerged vis-à-vis life and death and social living patterns. A decrease of growth in the 1970s and 1980s and in the 1990s the growth was due mostly to migration. The ageing population was a result of low fertility rates and a growing lifespan expectation. In 1900, the population under 15 years was $33.7 \%$ and over 65 years $5.7 \%$. In 2007 , elderly people surpassed young people by $17.3 \%$ against $15.4 \%$ respectively, which stands for 122 elderly per 100 young. However, it is particularly the population over 80 years that has increased in percentage and pace, so that in 2007 it amounted to $4.1 \%$ of the total population ${ }^{2}$. This trend is expected to be strengthened in the next years according to a projection by the National Institute for Statistics (Portugal). In 2060 young people will not represent more than $11.9 \%$ of the total population, while elderly people will reach $32.3 \%$.

1 Maria José Carrilho, Lurdes Patrício, “A Situação Demográfica Recente em Portugal”, Revista de Estudos Demográficos, 44 (2008), p. 45.

2 Statistics, www.ine.pt. 
The ageing process is particularly significant in rural districts, due to migration to urban areas and abroad, leading to an unsymmetrical distribution of populations. The decrease of young people and the increase of the elderly population mimic the duality between more economically developed regions and rural areas. At regional level, the ageing phenomenon reflects the division between regions that are economically more dynamic and attractive, on the one hand, and, on the other hand, regions that are characterised by structural backwardness, economic stagnation and social weakness, the exodus of large groups of the population and peripheral territoriality. On the whole, these regions become incapable of attracting investment and of using the potential of endogenous resources to keep populations.

Elderly people are not only more in number than before. They also live longer. The life expectancy has increased twelve years for men and fourteen years for women between 1960 and 2007. This is a result of the epidemiological and sanitary transition, which not only reduced the impact of infections, such as respiratory and digestive diseases, but also caused a rise in degenerative diseases such as tumours and circulatory disorders. While in 1960, death caused by degenerative diseases amounted to $35 \%$, in 2005 the number had risen to $55.6 \%$. (Table 1).

Table 1. Portugal: Main Causes of Death (2005)

\begin{tabular}{lccc}
\hline & $\mathbf{6 5 - 7 9}$ years & $\mathbf{8 0 +}$ years & Total \\
\hline Circulatory System & 32.4 & 42.5 & 34.1 \\
Tumours & 27.6 & 12.6 & 21.5 \\
Respiratory System & 9.2 & 13.9 & 10.5 \\
External Causes & 2.9 & 1.7 & 4.2 \\
Digestive System & 4.5 & 3.0 & 4.3 \\
Endocrinal and & 6.1 & 4.6 & 4.8 \\
metabolic diseases & & & \\
Infectious dis- & 1.6 & 1.0 & 2.1 \\
eases/AIDS & 9.6 & 13.2 & 11.8 \\
Non Specified & & &
\end{tabular}

Source: INE, Health Statistics 2005, 2006

\section{Social change, demographic behaviour and some vulnerability factors}

Ageing has implications not only for demography, but also for the society and the health system. It has transformed the familial institution and the intergenerational bonds of solidarity. The nuclear family with less children and a growing number of elderly transforms the natural balance of traditional demography. A context of deprivation and short-lived marriages further contributes to the progressive degradation of the traditional familial solidarity networks. The change in role models and the 
fact that more women are working also result in a reduction of elderly care, a greater isolation of elderly people and the absence of informal care, since women used to be the main informal health care providers.

The vast majority of elderly people live as couples, as husband and wife, but men usually die first. This affects how this group experiences familiar life. To live alone is more common among elderly people, especially in the case of women living as widows, no matter which region they live in. ${ }^{3}$ In 2006, 28.8\% of women over 65 years lived alone, compared to $9.4 \%$ of men living alone. This trend shows a tendency to increase the gap between men and women. In 2006 a higher percentage of the elderly lived either with a spouse $(44.2 \%)$ or alone $(20.7 \%)$.

Among the elderly who lived alone, besides being women and living on their own, the majority had retired from productive activities. In general terms, elderly people have low education levels, the women even lower than men: $64.7 \%$ of women compared to $41.3 \%$ of men had had no education at all.

The health system also faces new challenges due to the ageing population. The increase of the average lifespan is generally matched by a rise in physical and/or psychic dependency, which causes a lack of mobility and of autonomy, an increase in chronic diseases evolving slowly over time. This causes a rise in the numbers of consumers of specific health care systems and of their demands in terms of quality and complexity of health care.

By observing the average healthy life expectancy, we can estimate the number of years that men and women may expect to live without disabilities (Table 2). Although women have a higher life expectancy than men, the latter may expect to live longer without physical disabilities. This suggests the need for more health care, since ageing is to a large extent a female phenomenon.

Table 2. Healthy life expectancy (2006).

\begin{tabular}{lcc}
\hline & Male & Female \\
\hline E0 & 59.6 & 57.6 \\
E65 & 6.8 & 5.9 \\
\hline
\end{tabular}

Source: http://epp.eurostat.ec.europa.eu/portal/page/portal/statistics (checked November 11, 2008).

3 Sofia Leite, "Famílias em Portugal: breve caracterização socio-demográfica com base nos Censos 1991 e 2001”, Revista de Estudos Demográficos, 33 (2003), pp. 23-38. In 2006, elderly men lived mostly as a couple (82.9\%) while only $48.4 \%$ of elderly women of the same age lived with a spouse. (“Dia Internacional do Idoso - 1 de Outubro de 2007", Destaque, www.ine.pt)

4 "Dia Internacional do Idoso - 1 de Outubro de 2007", Destaque, www.ine.pt (opened December 18, 2009).

5 Employment Survey 2001 (INE, “O Envelhecimento em Portugal: Situação demográfica e sócia económica recente das pessoas idosas", Revista de Estudos Demográficos, 33, (2002), p.194 
According to the 1998/1999 National Health Survey, elderly women showed worse health conditions than men of the same age. However, both a high percentage of men and women perceived their health to be "poor" or "fair", and $12.7 \%$ even considered it to be "very poor". In the latest Health Survey (2005/06) women over 75 years perceived their health condition to be 'poor or very poor' (Table 3 ).

Table 3. Self-perception on health condition (\%), sex and age, 2005/2006.

\begin{tabular}{lccccccccc}
\hline & \multicolumn{3}{c}{ TOTAL } & \multicolumn{3}{c}{ MALE } & \multicolumn{3}{c}{ FEMALE } \\
\cline { 2 - 10 } & $\begin{array}{c}\text { Very } \\
\text { good/ } \\
\text { Good }\end{array}$ & Fair & $\begin{array}{c}\text { Poor/ } \\
\text { very } \\
\text { poor }\end{array}$ & $\begin{array}{c}\text { Very } \\
\text { good/ } \\
\text { good }\end{array}$ & Fair & $\begin{array}{c}\text { Poor/ } \\
\text { very } \\
\text { poor }\end{array}$ & $\begin{array}{c}\text { Very } \\
\text { good/ } \\
\text { good }\end{array}$ & Fair & $\begin{array}{c}\text { Poor/ } \\
\text { very } \\
\text { poor }\end{array}$ \\
\hline All ages & 53.2 & 32.8 & 14.1 & 59.3 & 30.2 & 10.4 & 47.4 & 35.1 & 17.5 \\
$>\mathbf{1 5}$ & 85.5 & 12.8 & 1.7 & 83.1 & 14.7 & 2.2 & 88.0 & 10.9 & 1.1 \\
$\mathbf{1 5 - 2 4}$ & 80.8 & 18.0 & 1.1 & 84.2 & 14.9 & 0.9 & 77.3 & 21.3 & 1.3 \\
$\mathbf{2 5 - 3 4}$ & 70.9 & 25.3 & 3.8 & 74.9 & 22.1 & 3.0 & 66.8 & 28.6 & 4.6 \\
$\mathbf{3 5 - 4 4}$ & 57.5 & 36.8 & 5.8 & 64.8 & 31.2 & 4.0 & 50.3 & 42.2 & 7.6 \\
$\mathbf{4 5 - 5 4}$ & 40.2 & 45.8 & 13.9 & 49.0 & 41.3 & 9.7 & 31.9 & 50.1 & 18.0 \\
$\mathbf{5 5 - 6 4}$ & 24.7 & 47.3 & 28.0 & 33.2 & 45.1 & 21.7 & 17.1 & 49.2 & 33.7 \\
$\mathbf{6 5 - 7 4}$ & 15.5 & 46.4 & 38.1 & 20.0 & 49.5 & 30.4 & 11.8 & 43.9 & 44.3 \\
$\mathbf{7 5 - 8 4}$ & 11.1 & 41.2 & 47.7 & 14.2 & 44.4 & 41.4 & 9.0 & 39.1 & 51.9 \\
$\mathbf{8 5 +}$ & 13.2 & 46.4 & 40.4 & 21.2 & 42.3 & 36.4 & 9.3 & 48.4 & 42.3 \\
\hline
\end{tabular}

Source: INSA/INE - Fourth National Health Survey (2005-2006).

Further aspects that may cause elderly people to be socially vulnerable are the poverty levels that affect a considerable proportion of this population group (Table 4). This affects not only the elderly living in single person households, but also other households, although the percentages for this group have shown a slight decrease in recent years due to the implementation of policies especially targeted at elderly people in the wake of Portugal's integration in the EU. However, in 2007, the risk of poverty was high among the elderly, with a $26 \%$ at-risk-of-poverty rate. It was particularly high for elderly living on their own, being $37 \%$, which is high above the average national percentage of $18 \% .{ }^{6}$ The origin of this problem lies in the fact that Portugal presents a very high inequality rate in the distribution of incomes, particularly in rural areas where ageing rates are very high and elderly people tend to live on their own, and the pensions are low. This contributes to increase the dependency and vulnerability of those, who already live with disability caused by illness and ageing. In 2001 the national disability rate amounted to $6.2 \%$ of which the over 65 years represented $12.5 \%$.

6 EU-SILC 2007 (www.ine.pt, opened February 08, 2009).

7 INE, "O Envelhecimento em Portugal: Situação demográfica e sócia económica recente das pessoas idosas”, Revista de Estudos Demográficos, 33, (2002), p.192. 
Table 4. At-risk-of-poverty rate before social transfers (\%), by sex and age group.

\begin{tabular}{|c|c|c|c|c|}
\hline $\begin{array}{c}\text { Data reference } \\
\text { period }\end{array}$ & Age group & Sex & $\begin{array}{l}\text { At-risk-of- } \\
\text { poverty rate } \\
(\%)\end{array}$ & $\begin{array}{l}\text { At-risk-of- } \\
\text { poverty rate } \\
(\%)\end{array}$ \\
\hline \multirow{7}{*}{2004} & $0-17$ years & MF & 25 & 36 \\
\hline & \multirow{3}{*}{$18-64$ years } & $\mathrm{MF}$ & 17 & 32 \\
\hline & & M & 16 & 30 \\
\hline & & $\mathrm{F}$ & 18 & 34 \\
\hline & \multirow{3}{*}{$65+$ years } & MF & 29 & 82 \\
\hline & & M & 29 & 82 \\
\hline & & $\mathrm{F}$ & 29 & 82 \\
\hline \multirow{7}{*}{2007} & $0-17$ years & $\mathrm{MF}$ & 21 & 30 \\
\hline & \multirow{3}{*}{$18-64$ years } & $\mathrm{MF}$ & 15 & 31 \\
\hline & & M & 14 & 30 \\
\hline & & $\mathrm{F}$ & 16 & 32 \\
\hline & \multirow{3}{*}{$65+$ years } & $\mathrm{MF}$ & 26 & 85 \\
\hline & & M & 24 & 83 \\
\hline & & $\mathrm{F}$ & 27 & 85 \\
\hline
\end{tabular}

Source: INE - Statistics Portugal, Statistics on Income and Living Conditions - EU-SILC.

The elderly are cumulatively affected by low educational levels, low income, physical and social isolation, and unfavourable health conditions. Poverty will then aggravate the social vulnerability and exclusion of the elderly.

\section{Ageing and Wellbeing}

As discussed elsewhere, the developmental model of Portugal privileged the western maritime regions, which caused the continued loss of demographic and economic vitality of the inland regions, which is replicated by the geographical distribution of ageing.

In a previous research project developed by the author and others ${ }^{8}$ a statistical indicator was developed to stratify a so-called "global indicator for demographic, economic and social well-being," applied to all Portuguese regions between 1993 and 2004. ${ }^{9}$ The social, economic and demographic well-being indicators were used

8 This project was supported by the Portuguese Foundation of Science and Technology (project reference POCI/DEM/58366/2004, "Regionalidade Demográfica e Diversidade Social”). The project was classified with Very Good (2005-2008) and its main conclusions await publication (Teresa Rodrigues et allii, Regionalidade Demográfica e Diversidade Social (Porto, 2009).

9 L. Chorão, L. Pereira, "Avaliação de qualidade de vida e bem-estar”, in Teresa Rodrigues et allii (ed.), Regionalidade Demográfica e Diversidade Social (Porto, 2009), pp.129-151. 
Map 1. Global indicators of demographic, economic and social wellbeing and ageing ratio

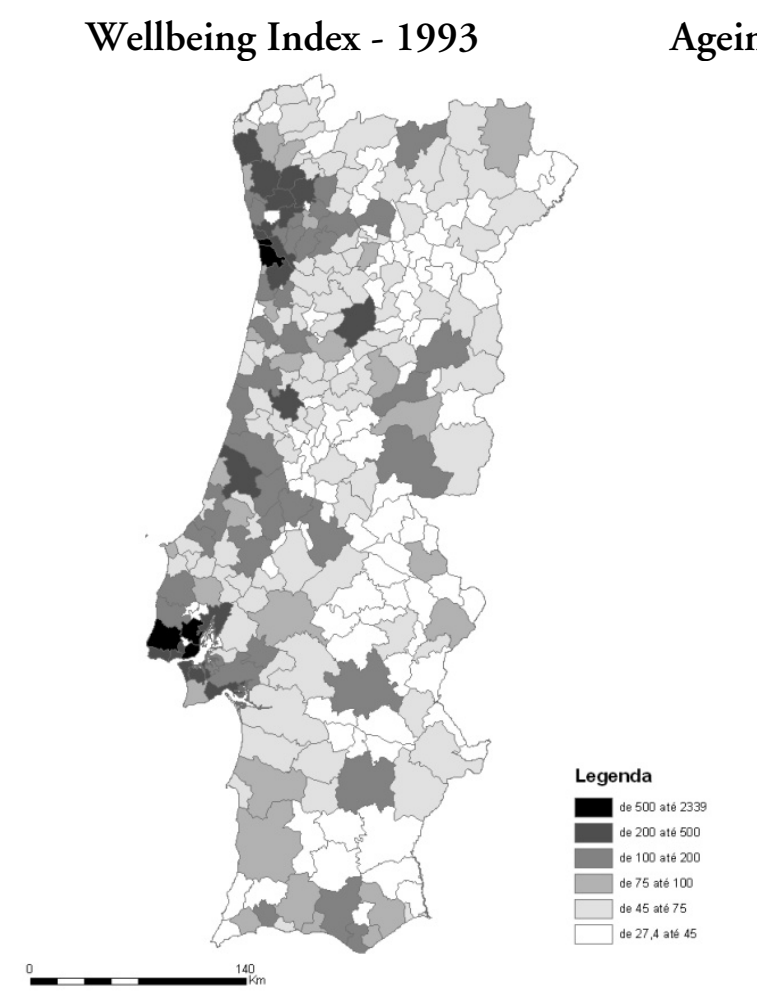

Wellbeing Index - 2004

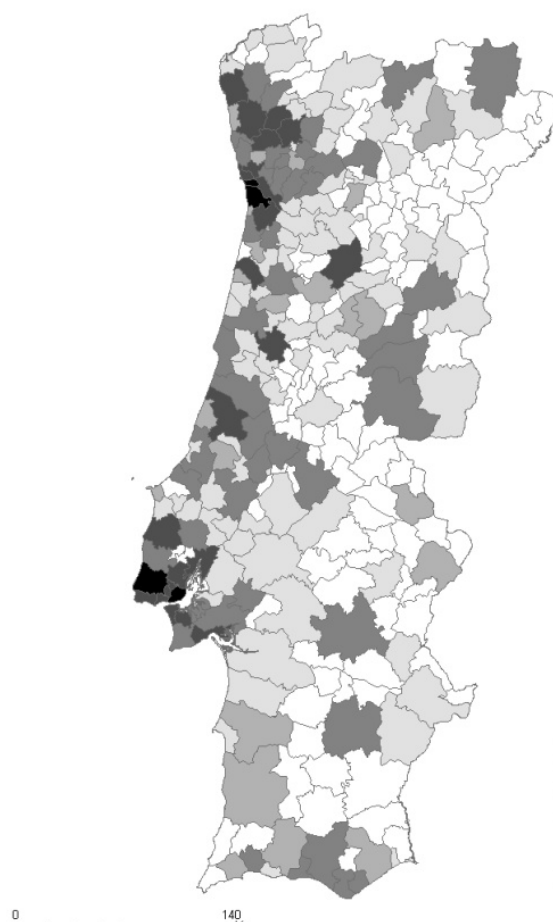

Ageing Ratio. 2001

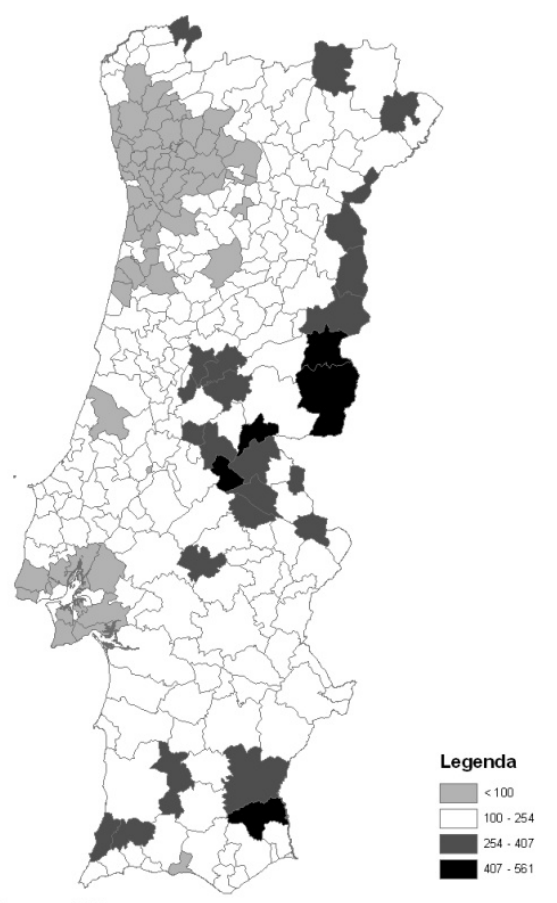

Ageing Ratio. 2007

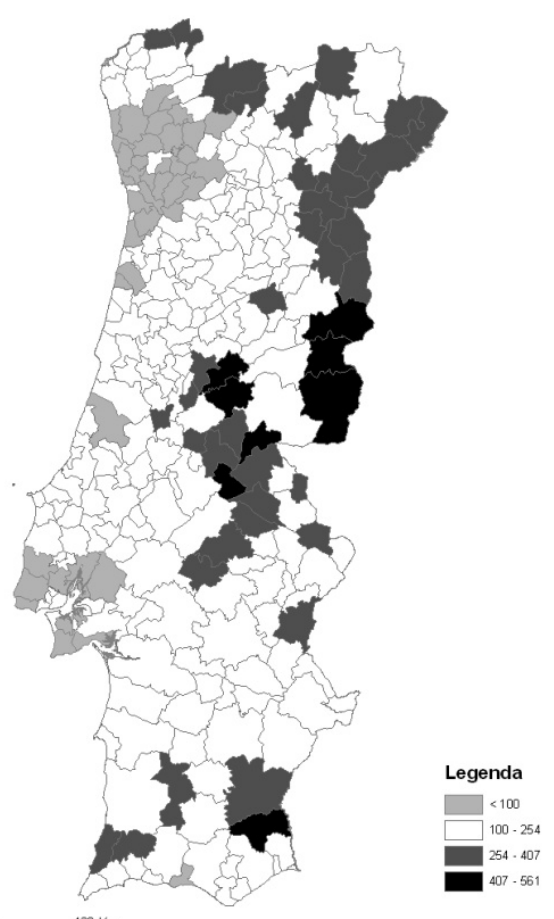

Source: L., Chorão, L. Pereira, "Avaliação de qualidade de vida e bem-estar", in T. Rodrigues et allii (ed.), Regionalidade Demográfica e Diversidade Social (Porto, 2009), pp.129-151; Ageing Ratio, map organized by the author. 
to convert automatically the Portuguese regions (concelhos) into homogenous population groups.

When compared to the "global indicators of demographic, economic and social wellbeing", the ageing indicator shows a global decrease of the well-being indicator values $^{10}$ and it gives relevance to the ageing process. While in 2001, 22\% of the regions (concelhos) showed an ageing indicator below 100, in 2007 the percentage had decreased to $15.6 \%$. Further, there is some matching of regions (concelhos) with the worse/better wellbeing indicators and the higher/lower indicators for ageing (Map 1). This causes a further unequal distribution among regions and a gap between the interior regions and the coastal regions. The former are essentially rural and medium-sized urban centres which tend to function as developmental regional foci are exceptional. The coastal regions are economically and demographically more dynamic.

The differences in regional development, in wealth distribution, in availability of services, and in well-being levels may again contribute to further worsen the inequality and vulnerability of elderly populations who are already affected by the consequences of unequal distribution of health equipments which are concentrated in urban areas ${ }^{11}$.

\section{Social Change / New Health Policies}

The ageing of the population has transformed the morbidity and mortality patterns. The main causes of morbidity and mortality are nowadays linked to chronic diseases that evolve slowly in time (Table 1). These cause the last years of life to be experienced as years of disability, of lack of autonomy and dependency (in several stages). These are the patients that have increased in number. They have more complex problems and therefore they require a more complex organizational structure with articulated multidisciplinary responses at several assistance levels.

The Portuguese national health care system includes a network of Health Care Centres for primary health care which however, has shown difficulties in adapting to the new demographic realities: few operational and specific answers to health care needs; poorly organised in geographic and demographic terms and in terms of

10 L, Chorão, L. Pereira, "Avaliação de qualidade de vida e bem-estar", in T. Rodrigues et allii (ed.), Regionalidade Demográfica e Diversidade Social (Porto, 2009), pp.129-151.

11 Cf. Paula Santana, "Poverty, social exclusion and Health", Social Science and Medicine, 55, (2002), p. 132-145; Paula Santana, "Ageing in Portugal: regional inequities in health and health care", Social Science and Medicine, 50, (2000) p. 1025-1036. 
the health professional / family /user ratio; without proximity and long-term care; with no links to other activities or social protection. ${ }^{12}$

The location of health care units and of medical staff is quantitatively and qualitatively a disadvantage for the elderly in rural regions. They find it more difficult than the elderly in urban areas to use the health care system due to their low income, morbidity problems, and costs associated to travel. ${ }^{13}$ We can therefore conclude that accessibility, quality and equity are not guaranteed for the elderly, the chronically ill, the dependent or people facing terminal life situations.

Furthermore, the organisational characteristics of the health care system are still excessively centralized to the hospitals (for acute and curable illnesses). Chronic patients are subjected to a curative model that is maladjusted to their situation and thus they loose quality of life and have to face very high health care expenses. The resources are poorly used in that frequently the same sophisticated expensive unnecessary diagnostic and treatment means are used repeatedly, with little or no advantage for the patient ${ }^{14}$.

Figure 1. Expenditures (\%).

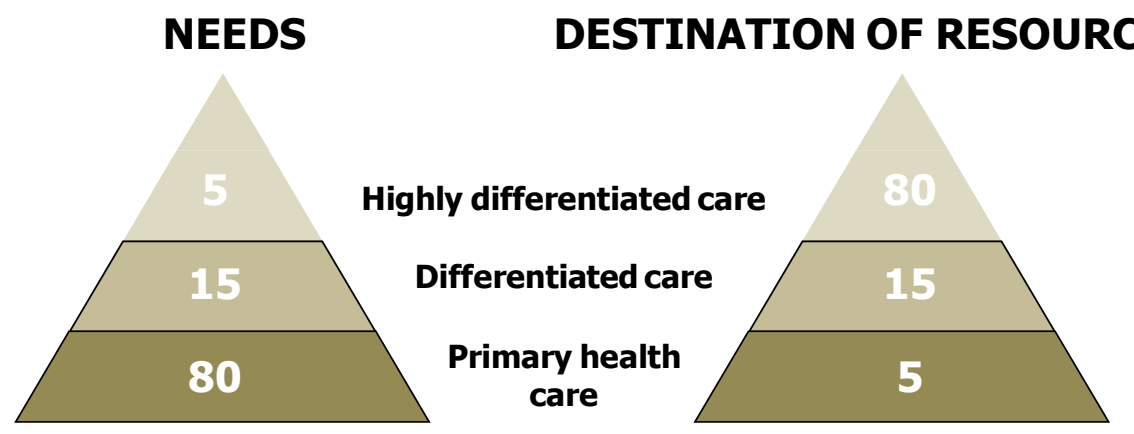

Source: Maria João Guardado Moreira, Ana Paula Sapeta, "Portugal: Ageing and new health policies" (2005).

In recent decades (in the 1980s and 1990s) there has been a maladjustment between how resources are used and effective needs of the health care system (Figure 1). It is

12 Maria João Guardado Moreira, Ana Paula Sapeta, "Portugal: Ageing and new health policies", paper presented in the meeting Saúde e mudança social nos paises europeus/ Health and social change in european countries, organised by Phoenix TN - Euopean Thematic Research Network on Health and Social Welfare Policie 213854_1_PT_Erasmus and Department of Political Studies, FCSH da UNL, 26 Septembre 2005.

13 Cf. Paula Santana, "Ageing in Portugal: regional iniquities in health and health care", Social Science and Medicine, 50, (2000), p. 1025-1036.

14 Maria João Guardado Moreira, Ana Paula Sapeta, "Portugal: Ageing and new health policies", paper presented in the meeting Saúde e mudança social nos paises europeus/ Health and social change in european countries, organised by Phoenix TN - Euopean Thematic Research Network on Health and Social Welfare Policie 213854_1_PT_Erasmus and Department of Political Studies, FCSH da UNL, 26 Septembre 2005. 
therefore necessary to use financial resources in an effective way, since in 2006 public expense on health care (GDP percentage) rose to $70.6 \%$ and represented $10.2 \%$ of the total public expense ${ }^{15}$, which is above the average of OECD countries (8.9\%) 16.

Legal provision was made to improve primary health care in 2005 through a Council of Ministers Resolution (nr 86/2005) with the aims to: reconfigure the health centres as pivotal for the entire primary health care system (an emphasis on health care services in the community); implement the family health care units; implement the local health care units. This document further presents the structuring principles for the health care of elderly and dependent people through a commission constituted for that effect: Comissão Para o Desenvolvimento dos Cuidados de Saúde às Pessoas Idosas e às Pessoas em Situação de Dependência. It is widely acknowledged that the lack of local long-term health care is the weak spot of the Portuguese national health care system, which falls short of the World Health Organisation and Council of Europe recommendations highlighting palliative care as the health politics first priority. The Misericórdias (Charity organisations) and some NGOs have been the only local long-term health care providers in Portugal.

2006 witnessed the approval of the National Network for Integrated Continuous Care (RNCCI), to be implemented over a ten-year period (2006-2016), with the aim of providing integrated continuous care services (convalescence, medium and long-term care, palliative care). This network is based on the co-operation between the Ministry of Health, the Ministry of Labour and Social Solidarity and social and private sector stakeholders. Geographically there are three levels of co-ordination: central, regional and local. Access wise there will be integrated co-ordination involving the hospital (discharge teams) and community care allowing early referrals; ongoing monitoring to match needs to care provision, locally and regionally.

\section{Conclusions}

Ageing is one of the most important phenomena of the recent Portuguese demographic evolution. It implicates social and health consequences which, when taken together and considered in their dual roles, determine the need for policies that will bring about the reform of the social and health systems. The increase of health care consumers determines the development of policies that will support and protect families' roles as health care providers and that will create local health care struc-

15 European Commission, Joint Report on Social Protection and Social Inclusion 2009 (ec.europa.eu/employment social/spsi/docs/social inclusion/2009/cf portugal final pt.pdf).

Downloaded April, 05, 2009.

16 OECD Health Data 2008 (http://www.oecd.org/dataoecd/43/2/40905146.pdf).

Download May, 31, 2009. 
tures, services and teams. All these policies will have to take into account the characteristics of the elderly population, which constitutes one of the most vulnerable groups, since a large majority has low income, low educational level, and poor access to health care.

The major challenges for policy makers and to the citizens in general, will be to identify the adjustments needed to the ageing population. In the long term, it will be crucial to guarantee that everybody has access to health care (including chronic and dependent patients); that geographical inequalities in access to health care are corrected; and that high-quality health care is accessible to all; besides working towards the financial sustainability of health care and social services (desirably integrated into a unique system). In the medium term, long-term and local care will have to be reorganised to improve national provision of palliative care units, to implement family health units (family, doctor and nurse) and create intermediate structures of multidisciplinary teams of medical care (doctor, nurse, social service mediator, psychologist, physiotherapist etc). It is further essential to promote longlife learning programmes for health professionals (at graduate and post-graduate educational levels and long-life learning). Concrete measures and support for families to help them care for elderly people/patients will also have to be developed. Finally, to respond to the social consequences of ageing parallel social policies are needed to complement social protection actions already in place ${ }^{17}$ in order to correct inequality conditions lived by elderly people.

Maria João Guardado Moreira is associate professor at Escola Superior de Educação of the Instituto Politécnico de Castelo Branco and researcher at CEPESE (Centro deEstudos da População Economia e Sociedade).

17 For instance Old Age Pensions, Invalidity and Old Age Social Pension, Solidarity Supplement for the Elderly. 


\section{References}

Carrilho, Maria José, Lurdes Patrício, "A Situação Demográfica Recente em Portugal”. Revista de Estudos Demográficos, 44 (2008), 35-80.

Chorão, L., L. Pereira, "Avaliação de qualidade de vida e bem-estar", pp.129-151 in Teresa Rodrigues, João Teixeira Lopes, Luís Baptista, Maria João Guardado, Moreira, (ed.), Regionalidade Demográfica e Diversidade Social, Porto, 2009.

European Commission, Joint Report on Social Protection and Social Inclusion 2009 (ec.europa.eu/employment_social/spsi/docs/social_inclusion/2009/cf_por tugal_final_pt.pdf). Downloaded April, 05, 2009.

Gonçalves, Cristina, Catarina Silva, "Pobreza e Exclusão Social nas Famílias com Idosos em Portugal", Revista de Estudos Demográficos, 35 (2004), 145- 169.

INE, “Dia Internacional do Idoso - 1 de Outubro de 2007”, Destaque (www.ine.pt, opened December 18, 2009).

INE, "O Envelhecimento em Portugal: Situação demográfica e sócia económica recente das pessoas idosas", Revista de Estudos Demográficos, 33 (2002),185208.

Leite, Sofia, "Famílias em Portugal: breve caracterização socio-demográfica com base nos Censos 1991 e 2001", Revista de Estudos Demográficos, 33 (2003), 2338.

Mauritti, Rosário, "Padrōes de vida na velhice", Análise Social, XXXIX: 171 (2004), 339-363.

Moreira, Maria João Guardado, Ana Paula Sapeta, "Portugal: Ageing and new health policies", comunicação apresentada ao encontro Saúde e mudança social nos paises europeus/ Health and social change in european countries, organizado pelo Phoenix TN - Euopean Thematic Research Network on Health and Social Welfare Policie 213854_1_PT_Erasmus Department of Political Studies, FCSH da UNL, 26 de Setembro de 2005.

Moreira, Maria João Guardado, Teresa Rodrigues, "As Regionalidades Demográficas no Portugal Contemporâneo", CEPESE Working Paper, 2008, http://cepese.up.pt/principal.php?.IDNivel=77 (checked November, 2008)

OECD Health Data 2008 (http://www.oecd.org/dataoecd/43/2/40905146.pdf). Downloaded May, 31, 2009.

Rodrigues, Teresa, Lopes, João Teixeira, Baptista, Luís, Moreira, Maria João Guardado, Regionalidade Demográfica e Diversidade Social, Porto, 2009

Santana, P. Geografias da Saúde e do Desenvolvimento. Evolução e Tendências em Portugal, Coimbra, 2005.

Santana, P., "Ageing in Portugal: regional iniquities in health and health care", Social Science and Medicine, 50 (2000), 1025-1036).

Santana, P., "Poverty, social exclusion and Health", Social Science and Medicine, 55 (2002), 132-145. 
Santana, Paula, Vaz e Fachada, "Estado de saúde dos Portugueses, uma perspectiva espacial”. Revista de Estudos Demográficos, 36, (2004), 5-28.

Veiga, Teresa, Maria João Moreira, Ana Fernandes, "Social changes and better health conditions of the Portuguese population. 1974-2000", Hygiea Interna ionalis, 4 (2004), 255-275 www.ep.liu.se/ej/hygiea/ra/027/paper.pdf (checked November, 2008). 